\title{
PERSPECTIVES
}

Invited article

Original version

DOI: http://dx.doi.org/10.1590/So034-759020180311

\section{GLOBAL JUNK: WHO IS TO BLAME FOR THE OBESITY EPIDEMIC?}

\section{WATCHING THE NUTRITIONAL TRANSITION IN BELIZE}

I visited southern Belize for the first time in 1976. As an archaeology graduate student, I was assigned the task of digging test trenches in a newly discovered ancient city, right at the beginning of the rainy season. As my excavations flooded, I spent time sitting in nearby houses chatting with Q'eqchi' Mayan people in the adjacent village. They convinced me to switch my career to cultural anthropology. Three years later, I returned to carry out research for my dissertation; I spent a year living in three different villages, helping people clear and plant their cornfields, tagging along on hunting and fishing expeditions, and engaging in many hours of chatting and interviewing people in their homes, often over a meal.

Everybody who could walk worked long hours every day. While the men cleared and planted, women carried heavy loads of corn for kilometers over difficult trails. Women chopped firewood, hauled water, tended pigs and fowl, and spent hours every day grinding corn for the daily staple of handmade tortillas and tamales. The diet was almost entirely locally based-over fifty kinds of plants grew in their gardens, and the forest provided a steady supply of wild foods, small game, and fish. There were a few small shops in the villages that carried canned goods, kerosene, basic medicines, soft drinks, rum, candy, and snacks, as well as wheat flour, sugar, and salt. While almost everyone had an adequate diet, nobody had much cash, so they could not afford foreign. A small can of mackerel, a handful of sweets for the kids, a jar of instant coffee- these were occasional treats. People built their own houses entirely from materials gathered in the rain forest. Thinking back to my time there, I realize that I never saw an overweight or obese Q'eqchi' person during the entire year.

When I left southern Belize in 1980, things were already changing. In the more accessible jobs on nearby farms, and they were starting to earn more cash from selling rice, pigs, and cacaoand, for a short time, marijuana. Metal roofs began to replace thatch, and people bought clothes, radios, and bicycles. 
Through the 1980s, I mostly lived and worked in other parts of the country, but I could see that the pace of change was increasing. The rutted trails I once walked became usable roads traveled by motorbikes and a few trucks; wells, schools and outhouses popped up; and a few villages got potable water systems and electric generators. Young people started to leave, for high school or to seek jobs, and many families moved to new villages founded along the main highway headed north and closer to the capital city, Belmopan.

In 2011, I took a group of nine students to Belize for a food studies field school sponsored by my university. The students spent three weeks living with Maya families in the northern villages on the highway, and then three weeks working in the tourist industry on the nearby coast. The idea was to see if we could find ways to get more local food from Maya farms onto the tourists' plates. One student, a bio-anthropologist, worked in a local health clinic.

What we found in the Maya villages was very similar to what the Times article "How big business got Brazil hooked on junk food" (Jacobs \& Richtel, 2017) describes in Brazil. Among the Maya in Belize, many people had unreliable and badly paid jobs in the banana plantations and shrimp farms, while others sold crafts and raised cash crops like citrus and cacao; few people were subsistence farming anymore, and there were huge disparities in housing and living conditions. Some women, especially those in richer families, tended to stay at home, cooking on gas stoves, and did little physical work; they married later and had fewer children, but with improved healthcare, infant mortality rates plummeted. In the 1980 s tuberculosis and periodic measles outbreaks killed many children and young people. Cell phones and TVs were everywhere.

Even though there were no fast food outlets and little food advertising, the locals' diet has become obesogenic. Wheat tortillas made from refined imported flour and lard or shortening have displaced corn; Danish or Brazilian canned meat has become common; and sugary soft drinks have replaced corn porridges or homemade cocoa. Cup noodles (high in salt, fat, calories, and preservatives) are a common lunch for busy workers. Overall there is much more meat in the diet-particularly chicken, which is produced at an industrial scale in Belize with subsidized feed. Children pester their parents for small change to buy sweet or salty snacks from the store. With the rise in the salt, sugar, and fat in the diet, overweight and obesity have become common, especially among women, and with them higher rates of diabetes and high blood pressure. Because these people are poor, rural, and poorly served by the health care system, they often cannot get the medications that would prolong their lives and stave off amputations and blindness.

This is the notorious "dual burden"-the combination of malnourishment and obesity, stunting and overweight, overeating and vitamin deficiency (Popkin, Adair, \& Ng, 2012). The cruelest thing of all is that as people become fatter, they are also more exposed to modern culture's idealized expectations of thinness, as peddled by the beauty and diet industries through television, which is mostly US cable channels. Though there is very little advertising targeted directly toward them, those US channels are rife with ads for fast food and convenience foods, as well as diet foods and diet plans. They watch programs with modelperfect hosts and shows like The Biggest Loser. It is hard to tell what effect these contradictory messages have on their diet, but because so much of their food is now imported, snack foods and empty calories are cheap and always available. Why has their environment become so obesogenic in a relatively short time?

\section{WHO IS TO BLAME?}

One of the most fundamental principles of modern capitalism is consumer sovereignty-the right of consumers to buy whatever they can afford-but some people have considerably more choices than others. It does not matter how much people would like to buy organic kale juice if they cannot find it. This is the point of discussions of food deserts, places where healthy foods are not available. The ideology of consumer sovereignty hides the practices that determine our range of choices. Manufacturers tell us that if there is a demand, someone will satisfy it, and that, therefore, they should not be blamed if there are bad health consequences, because they are just giving people what they want. Faced with food producers who say, "let the buyer beware," it is easy to fall back on the common narrative of the evil corporation, the seduction of the consumer, and the hapless suffering victim, but there are many other parties involved in the story.

Experience has taught us that corporations will sell whatever product is legal (and some that are not) to whomever they can, wherever they can, when they can make a profit or expand their market. They see this as their mission. Expecting corporations to ignore potentially lucrative markets is like asking a river to flow uphill. The only things that can stop giant multinationals from selling junk food to children are willing governments. Only governments can set in place legal constraints that forbid, license, tax, or regulate products in the name of public health. Most countries, for example, have some laws that regulate tobacco advertising and sales, even though many people want to smoke. International agreements and national laws forbid buying and selling many other products that are judged to be dangerous to public health (e.g., melamine) or the natural environment (e.g., DDT). Only public pressure supported by medical science can 
force governments to regulate a popular and profitable product. In the case of obesity, the need for public support and government action is so urgent that we find normally reserved academics willing to use terms like "epidemic," "crisis," and "emergency."

Many governments do not respond to public pressure or medical advice. Particularly in poor countries, wealthy multinational companies wield substantial power and political weight, and they use every legal means to fight local regulations that close or limit their access to consumers. All governments must weigh the financial influence of multinationals against the increasing cost of health services and treating diseases connected with diet and weight. Places where more than $40 \%$ of the adult population has diabetes or dangerously high blood pressure truly represent a public health emergency that requires heroic measures. Governments that cannot provide treatment and appropriate medicine for these conditions compound misery and kill people. No economy can thrive with a debilitated workforce, and NGOs, charities, and businesses alone cannot fill the gap.

Does this mean we should just blame governments for the crisis? No. We do have some shining examples of local and national governments actively fighting childhood obesity. For example, despite strong opposition from the food industry, Chile has taken dramatic action, regulating children's exposure to advertising for unhealthy foods, requiring warning labels, taxing soft drinks, and banning junk food from schools. We do not yet know if these measures have reduced the incidence of obesity.

More importantly, there are structural factors in capitalism that set up situations where convenience foods and snack foods become accessible and popular. These fit into the category of what Galtung (1969) and Farmer (1996) defined as "structural violence," aspects of the political economy that create the conditions of poverty and hunger, and then present the solution as cheap food. I prefer the term used by Indian social economist Naila Kabeer, "structures of constraint" (Kabeer, 1994), which makes it clear that while people may be making choices, they often have no healthy or positive options. This concept pushes us away from easy explanations that tend to blame the victims.

These structures of constraint are largely invisible because initially they do not appear to be about food at all. In many places, inequality in the ownership of property, particularly farmland, is a structure of constraint; if you do not have access to land, you cannot grow food. We have to include the property laws and corruption that often drive people off small farms to create giant cattle pastures, groves of oil palms, banana plantations, shrimp farms, and soybean fields. People who could once choose how to use their land end up as low-paid manual laborers on the plantations and cattle ranches, sometimes on the same land they used to own. On the coast, people who were once independent artisanal fishers are displaced by tourist development, the homes of the rich, and the kind of land development and fishing practices that destroy the resources that people once depended upon. Once-thriving selfsufficient communities disperse into isolated individuals and families who seek work as waiters, maids, janitors, street vendors, or underemployed laborers. To call this a "choice" is a cruel irony.

We also live in a global food economy that is structured by booms and busts, fads and fashions. Van Esterik (2006) found that many of the foods poor people depended upon in rural Laos vanished from their diets after the foods were discovered by foreign gourmets, causing prices to rise. What happens when the boom passes? McDonnell's (2015) work with quinoa farmers in Peru shows that at the peak of the boom, when prices were high, their diet shifted toward eating less nutritious non-indigenous foods. Now that quinoa is no longer a cutting-edge miracle food and is being grown more cheaply in the United States and other countries, its price in Peru has gone down, but the families have had a difficult time switching back to their quinoa-based diet. In many places, ethnicity, class, and status are closely connected to what you eat, and social mobility motivates a change in diet.

When small farmers leave the countryside for the city, they find many new structures that constrain their choices and options for food. Poor urban neighborhoods are often food deserts, located far from both affordable markets and workplaces. With multiple jobs, parents often depend on highly processed convenience foods, meaning that their children grow up with little appetite for the staples of rural people. And how can we blame them, when impoverished farmers usually have a relatively monotonous diet of porridge, tubers, or bread?

The distribution of retail trade and the proliferation of supermarkets constitute another structure of constraint. The decisions about what goes on supermarket and store shelves are hardly transparent, and they may even be industrial secrets. In the United States, for example, wholesalers and manufacturers of food must pay retail supermarket chains for shelf space; this is called a “placement fee," "slotting fee," or "slotting allowance." The Center for Science in the Public Interest argues that this practice favors large corporations over small and startup companies, reduces innovation, and makes it possible for the purveyors of junk food to place their products in crucial store locations, especially at checkout counters (Rivlin, 2016). You literally cannot shop in most American supermarkets, or any other chain retail store, without going by rack after rack of high-calorie confections and salty snacks.

The structures of constraint also include the rules of international trade, a system that still allows large rich and powerful countries to subsidize cheap food for export, while 
advocating "free trade." Price supports for corn in the Midwestern United States, for example, keep the price of high fructose corn syrup and corn oil low on the global market, where they displace local products. I will never forget eating grilled turkey tails from a street vendor in Ghana in the 1980s, a cheap export from the United States, where the fatty morsels are considered "waste"; Americans ate the lean cuts and sent the fat abroad. Gewertz and Errington (2010) document the same kind of trade in "meat flaps," fatty sheep bellies from New Zealand and Australia throughout the islands of the Pacific. They also investigated the growth of the instant noodle industry (Errington, Gewertz, \& Fujikura, 2013).

Of course, the global food industry takes advantage of these structures of constraint. When people no longer have access to fruit trees or honey, they are happy to buy cheap candy, soft drinks, and snack foods. When they can no longer grow their own corn, they will buy whatever cheap starchy staple is available in the local market, flavor it with salt, and cook it with plenty of fat. In Belize, local entrepreneurs cannot get their own snack foods, banana chips, or sesame sweets into the supermarkets. They do not have access to the best technology for preservation and packaging, and they lack resources to competitively advertise and distribute their products. Locally bottled coconut water spoils quickly, sesame candies melt, and the chips become rancid. Locals' snack foods cannot compete with colorful (and eternally unspoiled) tubes of Pringles ${ }^{\circledR}$ delivered weekly by truck.

The manufacturers of snack foods spend millions of dollars developing ways to dress up and display their products in convenient packages that will attract the eye and the dollar. They build their own racks and displays and find numerous ways to make it easier to see and buy their products. They are adept at turning out "greenwashed" foods-deceptively marketed and promoted as being environmentally friendly, healthy, or natural. Public health officials have to contend with shelf after shelf of foods that are scientifically designed to contain irresistible combinations of salt, sugar, fat, and enticing artificial flavors (Moss, 2013; Schatzker, 2015). If we accept the sovereignty of the consumer as the basic principle of retail trade, these cheap foods are the ones that people will gravitate toward, and no public health authority can match the advertising budget or political power of a multinational food corporation.

\section{CONCLUSION: WHAT IS TO BE DONE?}

Developments in richer countries offer some reason for hope. In the United States, obesity rates have peaked and are starting to decline, and people are eating less beef and more fish. The movement toward whole and organic foods is having a market influence, even in the absence of substantial regulation by the federal government. According to Popkin et al. (2012), over 20 countries have banned sugary beverages from schools, and 12 have banned $100 \%$ fruit juice. Nestle's (2017) book on sugary sodas proposes several different strategies for reducing their consumption. Certainly, governments at all levels have many tools they can use to directly improve peoples' diets.

As I argue above, the fundamental causes of obesity and related diseases are structural constraints, but I have omitted several other structural issues such as gender roles and income inequality. If we want to change these constraints, we need to begin with agricultural policy, trade agreements, land tenure, and the system of retail marketing, among other issues. Food is what Mauss (1990) called a "total social fact," which extends into every aspect of human life. Just as food studies requires the participation of many disciplines, food policies cannot just focus on diet and nutrition. We should not center our attention on the Q'eqchi' father who buys his daughter a cold Coke ${ }^{\circledR}$ on a hot day, but instead address the systems that make Coke ${ }^{\circledR}$ the only option.

\section{REFERENCES}

Errington, F., Gewertz, D., \& Fujikura, T. (2013). The noodle narratives: The global rise of an industrial food into the twenty-first century. Berkeley, CA: University of California Press.

Farmer, P. (1996). On suffering and structural violence: A view from below. Daedalus, 125(1), 261-283.

Galtung, J. (1969). Violence, peace, and peace research. Journal of Peace Research, 6(3), 167-191

Gewertz, D., \& Errington, F. (2010). Cheap meat: Flap food nations in the Pacific Islands. Berkeley, CA: University of California Press.

Jacobs, A., \& Richtel, M. (2017, Sep. 16). How big business got Brazil hooked on junk food. New York Times. Retrieved from https://www.nytimes. com/interactive/2017/09/16/health/brazil-obesity-nestle.html

Kabeer, N. (1994). Reversed realities: Gender hierarchies in development thought. London, UK: Verso.

Mauss, M. (1990). The Gift: Forms and functions of exchange in archaic societies. London, UK: Routledge.

McDonnell, E. (2015). Miracle foods: Quinoa, curative metaphors, and the depoliticization of global hunger politics. Gastronomica, the Journal of Critical Food Studies, 15(4), 70-85. doi:10.1525/ gfc.2015.15.4.70

Moss, M. (2013). Salt, sugar, fat: How the food giants hooked us. New York, NY: Random House.

Nestle, M. (2017). Soda politics: Taking on big soda (and winning). New York, NY: Oxford University Press. 
Popkin, B. M., Adair, L. S., \& Ng, S. W. (2012). The global nutrition transition: The pandemic of obesity in developing countries. Nutrition Reviews, 70(1), 3-21. doi:10.1111/j.1753-4887.2011.00456.x

Rivlin, G. (2016). Rigged: Supermarket shelves for sale. Washington, DC: Center for Science in the Public Interest. Retrieved from https:// cspinet.org/sites/default/files/attachment/Rigged\%2oreport_o.pdf
Schatzker, M. (2015). The Dorito effect: The surprising new truth about food and flavor. New York, NY: Simon \& Schuster.

Van Esterik, P. (2006). From hunger foods to heritage foods: Challenges to food localization in Lao PDR. In Richard Wilk (Ed.), Fast food/slow food: The cultural economy of the global food system (pp. 83-96). Lanham, MD: AltaMira Press. 